\title{
Beneath the surface: community assembly and functions of the coral skeleton microbiome
}

\author{
Francesco Ricci ${ }^{1}$, Vanessa Rossetto Marcelino², Linda L. Blackall ${ }^{1}$, Michael Küh ${ }^{3,4}$, Mónica Medina ${ }^{5}$ and \\ Heroen Verbruggen ${ }^{{ }^{*}}$ (D)
}

\begin{abstract}
Coral microbial ecology is a burgeoning field, driven by the urgency of understanding coral health and slowing reef loss due to climate change. Coral resilience depends on its microbiota, and both the tissue and the underlying skeleton are home to a rich biodiversity of eukaryotic, bacterial and archaeal species that form an integral part of the coral holobiont. New techniques now enable detailed studies of the endolithic habitat, and our knowledge of the skeletal microbial community and its eco-physiology is increasing rapidly, with multiple lines of evidence for the importance of the skeletal microbiota in coral health and functioning. Here, we review the roles these organisms play in the holobiont, including nutritional exchanges with the coral host and decalcification of the host skeleton. Microbial metabolism causes steep physico-chemical gradients in the skeleton, creating micro-niches that, along with dispersal limitation and priority effects, define the fine-scale microbial community assembly. Coral bleaching causes drastic changes in the skeletal microbiome, which can mitigate bleaching effects and promote coral survival during stress periods, but may also have detrimental effects. Finally, we discuss the idea that the skeleton may function as a microbial reservoir that can promote recolonization of the tissue microbiome following dysbiosis and help the coral holobiont return to homeostasis.
\end{abstract}

\section{The expanding field of coral skeleton microbial ecology}

The coral holobiont comprises the coral polyps and a rich microbial community of prokaryotes, microeukaryotes and viruses (Fig. 1) [1, 2]. Anatomically, it consists of a thin film of mucus and tissue over a voluminous, porous calcium carbonate skeleton. The past decades have seen significant advances in our understanding of the diversity and roles of endosymbiotic algae (zooxanthellae in the family Symbiodiniaceae) and other microbes inhabiting the coral tissue and mucus $[1$, 3-5], while the microbiota residing in the skeleton have been side-lined. However, in the last few years, several studies have shed light on the ecology, biodiversity, physiology and metabolism of the skeletal microbiome, bringing its complexity into focus and raising hypotheses about its functions within the coral holobiont.

\footnotetext{
* Correspondence: heroen@unimelb.edu.au

'School of BioSciences, University of Melbourne, Parkville 3010, Australia Full list of author information is available at the end of the article
}

Metabarcoding studies show a much higher biodiversity than anticipated, and a strong spatial structure of prokaryote distributions [6]. Ecological, physiological and more recently metagenomic studies are clarifying the functions of skeletal microbiota in the holobiont, including recycling of nutrients like nitrogen and sulphur $[7,8]$, providing alternative sources of energy $[8,9]$, decalcifying the skeletal matrix [10] and shaping the physico-chemical properties of the skeleton [11, 12]. This review aims to integrate ideas in the rapidly expanding field of coral skeleton microbial ecology and puts the fragmented information into an ecological context.

\section{Diversity and distribution of the skeletal microbiome}

Eukaryotic and prokaryotic microorganisms are very diverse and abundant across the $\mathrm{CaCO}_{3}$ skeleton (Figs. 1 and 2) $[2,6,13-24]$ and are called endoliths due to their rock-dwelling nature. Among the eukaryotes are 


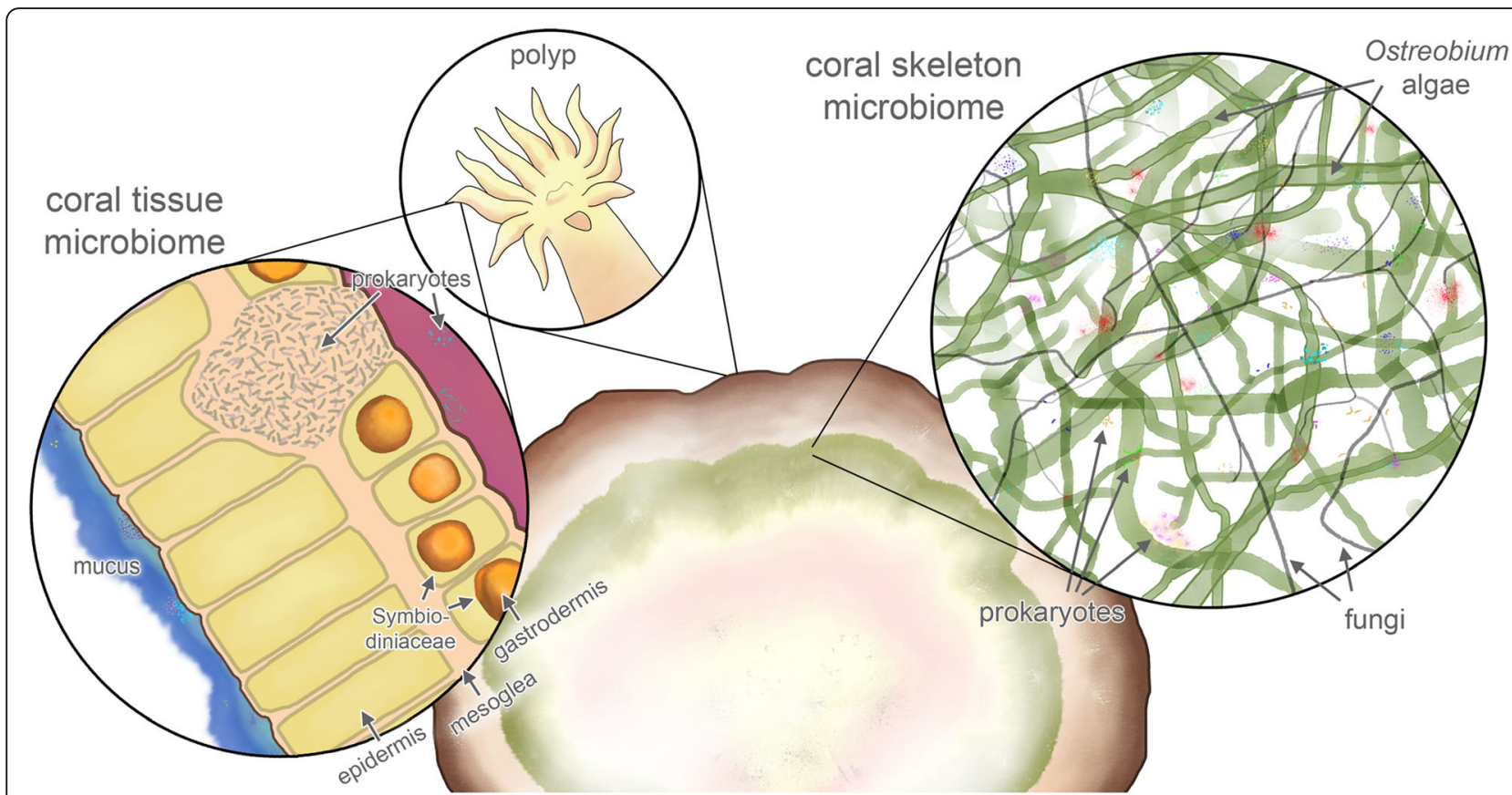

Fig. 1 Cross-section of a coral skeleton, showing the microbiome associated with the tissue and mucus (left inset) and the skeleton (right inset). In the tissue, Symbiodiniaceae provide the coral with sugars through photosynthesis, and a rich prokaryotic microbiome is associated with mucus, epidermal and gastrodermal tissue layers, which often show bacterial aggregates. In the skeleton, a remarkably species-rich microbiome including the green alga Ostreobium, fungi and prokaryotes is found. The illustration depicts a relatively young massive coral species; older skeletons often have a more complex layered microbiome (see section "The skeleton as an environmental and biological record-keeper")

different groups of algae, sponges, fungi and protists, some of which actively bore into limestone, while others inhabit skeletal pores or cavities made by other microorganisms [2, 14, 25, 26]. Alpha- and Gammaproteobacteria are predominant bacterial classes $[2,27]$ and recent studies show that prokaryotes are even more diverse in the skeleton than in the coral tissue or mucus [28].

Eukaryotic green algae are abundant in the skeletons of live corals, exceeding the biomass of Symbiodiniaceae in the tissue by 16 times [29]. The green alga Ostreobium is the most common genus, present in the vast majority of stony coral samples [2, 29-31]. Its simple morphology and the laborious nature of isolating and culturing endolithic green algae has limited our knowledge about the biodiversity of these organisms, but culture-independent sequencing approaches have recently shown a massive biodiversity of green algal endoliths in coral skeletons, including a lineage of about 80 different Ostreobium species and several other entirely unknown family-level lineages [13, 24], suggesting that distantly related green algal lineages may have gone under the name "Ostreobium" in previous studies.

Fungi are also often reported in coral skeletons $[2,16$, $17,19,25,32]$. They can feed on endolithic algae and coral polyps $[15,17]$ and are best known for their detrimental roles toward stony and soft corals [15-17, 33, 34]. Fungal hyphae growing toward coral tissue can be impeded or stopped by the host by encapsulating them in aragonite cones, preventing tissue perforation [18]. Fungi are also common in healthy corals and can coexist with the rest of the coral microbiome in a healthy equilibrium [15].

The spatial distribution of the microbial biodiversity in the skeleton is an active area of research. Endolithic algae are ubiquitously present in tropical coral reefs [24], but have also been recorded in corals from high-latitude areas such as the Chilean fjords [35]. They occur in shallow and deeper waters $(>100 \mathrm{~m})$ as well as in cavedwelling corals [29, 31, 36, 37], and there is some evidence suggesting that the distribution of Ostreobium lineages is structured along a depth gradient [38]. At much smaller scales, there is strong patchiness in microbial distributions within individual colonies, where the prokaryotic community shows strong species turnover even at centimetre scales in the outer skeleton of individual colonies [6]. Endolithic algae, which actively tunnel their way through the skeletal matrix, show more homogeneous distributions in comparison to the prokaryotes [6]. It is likely that spatial differences also exist across the vertical axis of the coral colony, from its surface deeper down into the skeleton, as distinct green, grey and occasionally pink layers are visible to the naked eye (Figs. 1, 2 and 3) [16, 26, 39].

Endolithic organisms are abundant in a variety of coral species, including massive species (Fig. 2a, c) and smaller 


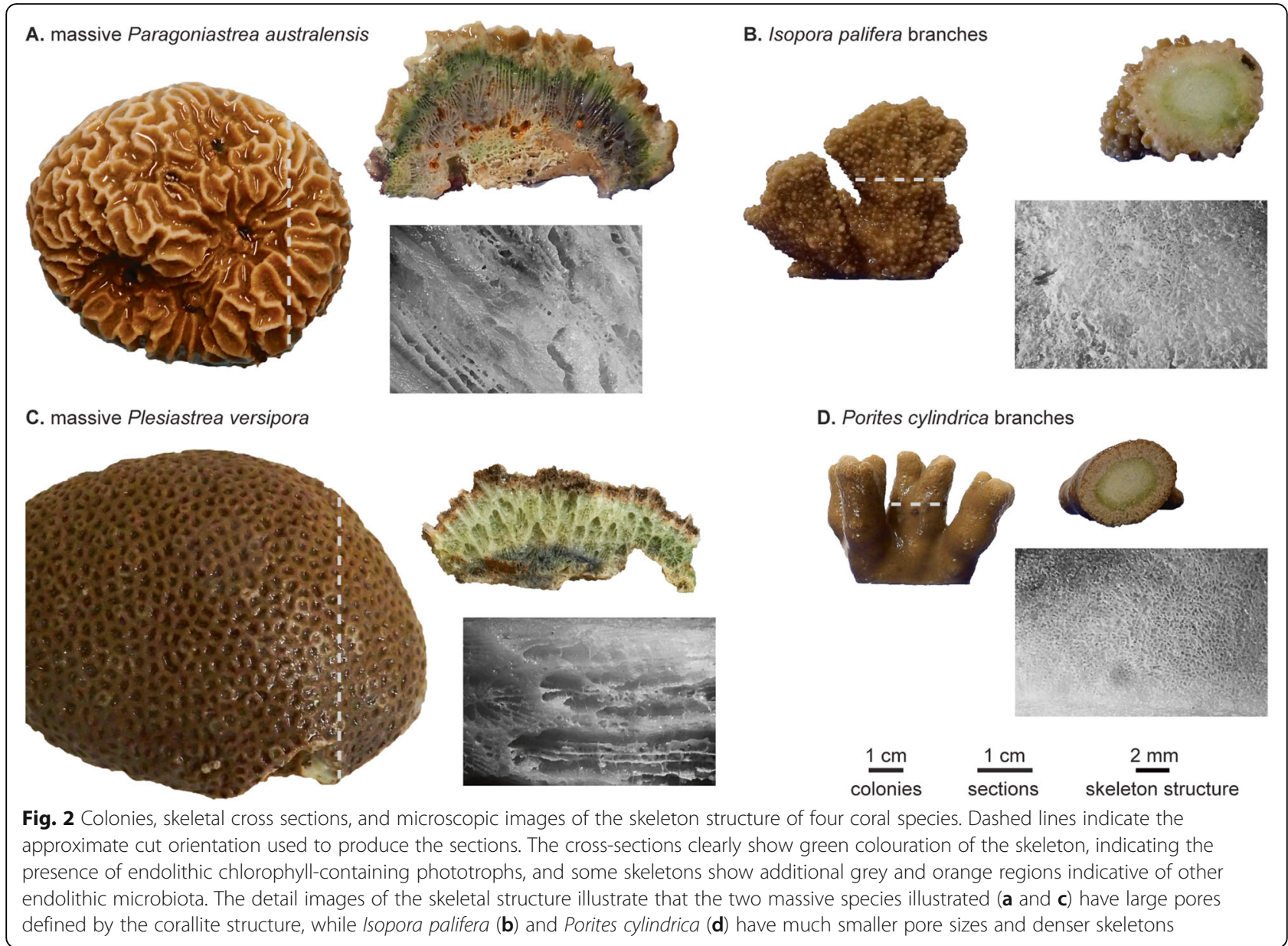

branched forms (Fig. 2b, d). Like certain coral tissueassociated bacteria [40, 41], some endolithic microbes are consistently found in association with specific coral species [24]. For example, the endolithic community of massive Porites spp. was found to be distinct and more diverse when compared to the branching corals Seriatopora hystrix and Pocillopora damicornis [42], and

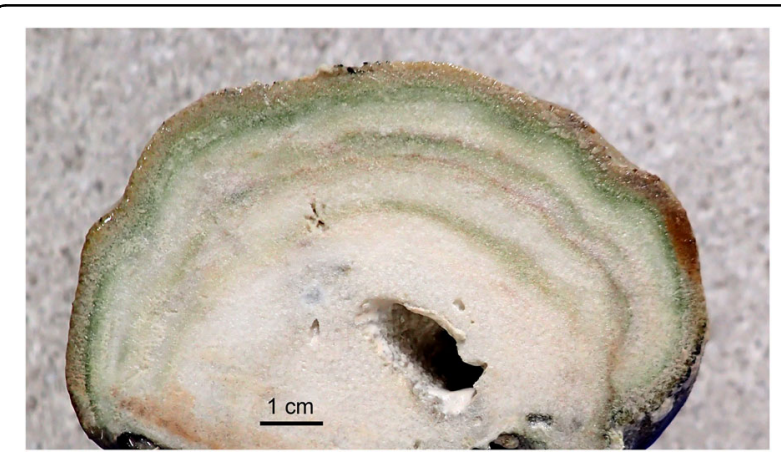

Fig. 3 Cross-section through the skeleton of a small Porites /utea coral head showing bands of biogenic origin at multiple depths. For larger colonies, such bands may provide a decadal (or longer) record of coral biology and climate if the information can be accessed a recent study found that the endolithic microbiome correlates with host phylogeny over a range of coral species [28]. Whether these correlations reflect speciesspecific interactions, phylosymbiosis, an effect of coral growth forms and skeletal microhabitats, or which combination of these, remains to be investigated in detail.

\section{Micro-niches in the skeleton}

Scleractinian corals have diverse ecological micro-niches shaped by physico-chemical gradients across the various tissue and skeleton compartments (Fig. 4) [11, 12, 43]. These gradients are affected by the environment surrounding the coral holobiont $[10,12,44]$, the skeletal microstructure $[45,46]$, and the physiology of holobiont members [11, 47]. Light is a crucial source of energy in this system, and the great majority of photosynthetically active radiation is absorbed by Symbiodiniaceae in the coral tissue [48] with only a small fraction penetrating into deeper layers (Fig. 4) [12, 43, 49, 50]. Inside the skeletons of shallow-water corals, mostly the far-red wavelengths $(>700 \mathrm{~nm})$ remain [12]. These low-energy photons can be harvested by phototrophic endoliths through a variety of mechanisms including specialised 


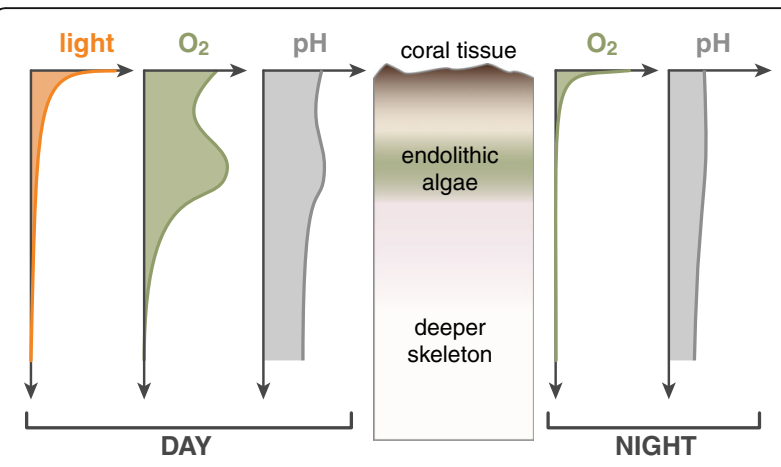

Fig. 4 Micro-environmental gradients through a vertical crosssection of the skeleton of a massive coral species dominated by an Ostreobium algal band. During the day, sunlight gets depleted in the coral tissue with only small amounts of mostly far-red light reaching the skeleton. Oxygen levels are high near the tissue and in the endolithic algal zone due to photosynthesis, and this is also reflected in elevated $\mathrm{pH}$ in those zones. During the night, oxygen gets depleted from the skeleton by respiration and $\mathrm{pH}$ levels drop

pigments (chlorophylls $\mathrm{d}$ and $\mathrm{f}$, bacteriochlorophylls) and uphill energy transfer [51-53]. Inside the skeleton, $\mathrm{O}_{2}$ production through photosynthesis is most pronounced in the green layer, creating a local $\mathrm{O}_{2}$ maximum (Fig. 4) [11]. Oxygen diffuses through the porous skeletal matrix into shallower and deeper parts of the skeleton, where it is consumed, and $1-2 \mathrm{~cm}$ below the maximum, the skeleton is completely anoxic [11]. The autotrophic metabolism of photosynthetic endoliths is also responsible for increasing $\mathrm{pH}$ in the medium, this process having a stronger influence on skeletal $\mathrm{pH}$ than the outside environment [43]. The dissolution process of $\mathrm{CaCO} 3$ which takes place both by day and at night, increases $\mathrm{pH}$ and the total alkalinity of the system [54].

Information on how skeleton architecture affects micro-niches is scarce, but the great variety of coral growth forms and skeletal features are likely to contribute to shaping the physicochemical characteristics of the colony. Light in the skeleton is scattered by the skeletal microstructure [55], with different coral species having been shown to have different scattering properties [46]. The association between skeletal structure and other physicochemical properties have not been investigated in detail, but one could hypothesise that porous and highly interconnected skeletons (e.g. Fig. 2a, c) may allow more diffusion of liquids and gases, leading to gentle environmental micro-gradients, while denser skeletons (e.g. Fig. 2b, d) may show opposite dynamics, with steep gradients driven by local biological processes (e.g. $\mathrm{O}_{2}$ peak corresponding to the endolithic algal layer, Fig. 4).

The micro-environments within the skeleton are subjected to a pronounced day/night cycle, being dominated by photosynthesis during the day and respiration during the night [43]. In daylight, $\mathrm{O}_{2}$ is produced and the environment becomes more alkaline due to $\mathrm{CO}_{2}$ removal, with $\mathrm{pH}$ values exceeding 8.5 (Fig. 4) [43]. The dominance of heterotrophic metabolisms during the night leads to quick consumption of the produced $\mathrm{O}_{2}$ (Fig. 4), shifting the environment to near-anoxia [11], and leads to a sharp drop of the $\mathrm{pH}$ by almost one $\mathrm{pH}$ unit [43]. After a few hours of darkness, the produced $\mathrm{O}_{2}$ is totally consumed in many skeletal zones. Anoxia promotes dinitrogen fixation by diazotrophic bacteria, although their activity in coral skeleton has been recorded even during the day [56].

\section{Community assembly processes}

The recent progress in coral skeleton microbial ecology allows us to form a working hypothesis about community assembly and functioning in the skeleton. We propose that the skeleton sustains a highly diverse but functionally redundant microbial community that is shaped by micro-niche partitioning, priority effects and evolutionary associations.

Niche partitioning over different spatial and temporal scales is a commonly observed process that supports biodiversity by preventing competition among species and allowing their co-existence [57]. The coral skeleton certainly has multiple physico-chemical micro-niches, spatially across depth layers, and temporally during day/ night cycles, seasons and life stages. These micro-niches sustain microorganisms from a range of functional groups, including aerobic and anaerobic bacteria, phototrophs, diazotrophs, decomposers, and microorganisms producing signalling metabolites and antimicrobial compounds $[2,15,42,56]$. Limited dispersal is another factor that may contribute to the high biodiversity of coral skeletons. Prokaryotes living at equivalent depths inside the skeleton show a remarkably strong species turnover at centimetre scales [6]. In Porites for example, a coral skeleton fragment of $\sim 0.23 \mathrm{~cm}^{3}$ contains about $25 \%$ of the prokaryotic diversity observed in the outer skeleton of the entire colony, indicating that microbial distribution is patchy even within ecologically homogeneous depth layers [6]. Spatial and temporal heterogeneity of environmental conditions promotes functional redundancy [58] and favours ecosystem stability [59, 60], which we expect to be important traits of the skeletal microbiome. We propose that environmental gradients and microbial interactions (e.g. competition, mutualism) in the limestone substrate result in patchy assemblages of microorganisms at very small spatial scales, characterised by high species diversity and functional redundancy in the skeletal microbiome of living corals.

Priority effects, the impacts that a species can have due to early colonisation of a habitat, likely play a strong role 
in shaping the species composition of the endolithic community, especially in young corals. A recent study reported Ostreobium in skeletons of coral recruits within the first week of larval settlement, and the algal colonisation increased with colony age, leading to a complex network of filaments of endolithic eukaryotes throughout the entire skeleton (Fig. 1) [44]. One can hypothesise that the first Ostreobium species to colonise and drill into the coral skeleton can shape their endolithic niche and likely remain predominant in the green endolithic layer through the life of the coral. A similar mechanism has been proposed to explain the assembly of the first gut microbiome in infants and its long-lasting effects on human health [61]. Besides priority effects, age-related changes in the endolithic community assembly are likely to occur. In fact, it has been shown that larger corals have a more diverse skeletal microbiome than smaller (and likely younger) colonies [62], and that prokaryotic species composition changes with the size of colonies [28]. These observations may reflect natural successional processes that occur over the course of coral development, and/or the ability of larger corals to sustain more diverse micro-niches. External factors may also play a role, including climate anomalies, physical disturbances (e.g. parrotfish grazing) and other factors that may transform community assembly patterns in the skeleton $[44,63]$. The most extreme example is seen during coral bleaching and death, when photobionts come to dominate the endolithic community $[64,65]$.

Phototrophs are likely to be keystone organisms in the endolithic community, given their disproportionally important role in community assembly. The anaerobic photoautotrophic Prosthecochloris, a dinitrogen-fixing green sulphur bacteria, is predominant in Isopora corals [14], while they are only present in low relative abundances in other corals dominated by Ostreobium $[2,42]$. In contrast to an Ostreobium-dominated environment, the anoxygenic photosynthetic green sulphur bacteria only thrive in an oxygen-poor skeletal environment, and have strong effects on nitrogen and sulphur cycling via their metabolism, which has downstream effects on the assembly of the skeletal microbiome [7]. An active field of research is to determine whether recently discovered endolithic lineages (e.g. different Ostreobium species and bacterial lineages) have distinct eco-physiological traitsand hence may trigger distinct community assembly patterns-and which ones are functionally redundant.

\section{The skeleton as an environmental and biological record-keeper}

Because the rate and density of $\mathrm{CaCO}_{3}$ deposition by corals varies seasonally, the skeleton has easily recognisable growth rings similar to those produced by trees on land [66]. Like in trees, these rings can be used to estimate colony age and growth rate, and thus serve as a record for historical climate as well as coral bleaching $[67,68]$. Coral skeletons have been used for a long time as a recordkeeper of environmental information. Long-lived massive corals are a reliable proxy for historical $\mathrm{pH}$ fluctuations (Reynaud et al. 2004), which suggest that natural $\sim 50$ years $\mathrm{pH}$ oscillation could mitigate the impact of ocean acidification on coral reef ecosystems [69]. Stable isotopes of skeletal materials have been used to reconstruct past variations of sea surface temperature [70] and to study the influence of anomalous climatic oscillation (e.g. El Niño/ Southern Oscillation) on coral biology [71]. Recent work has shown that some coral species are more suitable than others to serve as a climate proxy, and that data are influenced by the biology of the chosen specimen [72]. Skeletal intra-crystalline $\delta^{15} \mathrm{~N}$ has been used to trace excess nutrient loading in reef ecosystem [73], which, coupled with low $\mathrm{pH}$, can enhance corals' sensitivity to bioerosion [74]. $\delta^{15} \mathrm{~N}$ measurements can be a useful tool to distinguish among different nitrogen sources and shed light on the impact of anthropogenic nitrogen fluxes into reef ecosystems. Interestingly, besides this historical environmental record, older corals can also show multiple coloured bands of biological origin in their skeleton, with deeper greenish or greyish bands in addition to the green band just underneath the coral tissue (Fig. 3). At least in some corals, these coloured bands correspond to annual growth patterns [75]. The deeper bands are likely remnants of past blooms of endolithic algae, often consumed by fungi giving them a greyish colour $[16,75]$, while it is not always clear what deeper green bands represent. One could hypothesise that they are dead algae not yet consumed by fungi, but it is also possible that some of these bands harbour live phototrophic microorganisms specialised in different light environments. Green photosynthetic bacteria, for example, are known to thrive in extreme shade due to efficient light harvesting by their chlorosomes [76]. In any case, the skeleton is a complex structure, where niche differentiation along microenvironmental gradients appears to be superimposed upon a historical record of biological processes that spans decades, potentially even centuries in old colonies. Developing the appropriate methods to probe this record of biological processes and environmental conditions over time (e.g. by ancient DNA analysis, isotopic measurements, pigment analysis, and culturing microbiota from different bands) has the potential to shed light on the increasing impact of bleaching and human activities on coral holobionts.

\section{Implications for the coral Nutritional exchanges}

Corals rely on nutritional interactions with their microbiome to succeed in oligotrophic environments. The endolithic community may participate in the holobiont metabolism by providing and recycling substrates and 
nutrients. Organic compounds produced and excreted by photosynthetic organisms (and potentially other autotrophs) in the skeleton can fuel other members of the holobiont including fungi and other heterotrophic endoliths [15]. Importantly, carbohydrates produced in a green Ostreobium band were shown to be translocated to and incorporated into the coral tissue [77]. While the nature of the translocation is unclear, it suggests an established metabolic interaction between endolithic algae and corals [78].

The skeleton has also been proposed as an important site of inorganic nutrient regeneration. It is well known that, in comparison to the surrounding environment, the skeletal pore water is enriched in labile nitrogen and phosphorus species $[79,80]$, and that active dinitrogenfixing bacteria are present in the skeleton [56]. A recent metagenomic study revealed a wide range of genes involved in nitrogen and sulphur biochemical pathways in the endolithic microbiome, and it is likely that such metabolic functions can be carried out by many skeletal bacteria $[7,8,14]$. Oxygen availability is also important to the coral and its microbiota [81], and the dynamics of this element in the skeleton is largely determined by algal and cyanobacterial photosynthesis and microbial respiration [11]. The degree to which $\mathrm{O}_{2}$ and other nutrients are recycled within the skeleton and exchanged with the coral remains to be determined, but studies showing that carbon and nitrogen get transferred toward to the coral tissue $[8,9,77]$ suggest that the skeleton is a source of nutrients for the coral.

\section{Skeletal decalcification}

The structure of corals and the entire reef system depends on the balance of calcification and decalcification, both of which are strongly biologically mediated $[45,82]$. Many endolithic organisms including cyanobacteria, algae and fungi contribute to bioerosion of the coral skeleton [30, 82, 83], but the green alga Ostreobium is by far the most important agent of skeletal deterioration, responsible for $60-90 \%$ of microbial carbonate removal in coral skeleton [30, 65]. Most quantitative information on bioerosion comes from experiments on dead coral skeleton [30, 54], where microbial bioerosion rates are significant: up to $1.1 \mathrm{~kg} \mathrm{CaCO}_{3}$ dissolution per $\mathrm{m}^{2}$ of exposed substrate area per year [26], corresponding to about $20 \%$ of the annual $\mathrm{CaCO}_{3}$ production in coral reefs [54]. Much less knowledge is available for live corals, although it is known that less skeletal burrowing takes place in living corals than in dead carbonate skeletons. Nonetheless, microborers are present throughout the skeleton in living corals from very early developmental stages [44], and in the more densely populated areas of mature skeletons, more than $25 \%$ of the skeletal volume is occupied by microborers [26], implying substantial decalcification of live coral skeletons. Microbial bioerosion is known to increase at higher temperatures and lower $\mathrm{pH}$, and it has been estimated that by the year 2100 , coral endoliths will dissolve ca. $70 \%$ of the yearly reef $\mathrm{CaCO}_{3}$ production [54, 84], suggesting that this process will contribute to accelerated reef deterioration (and possibly coral fragility) in future ocean conditions $[10,84]$.

\section{Diversity-mediated coral health and resilience}

During disease, the coral microbiome composition shifts from homeostasis to a state of dysbiosis [3, 85, 86]. This shift is often triggered by environmental stressors like high temperature, and from a microbial perspective is characterised by a reduced population of beneficial species and a higher abundance of potentially harmful ones, some of which reside in the skeleton. For example, endolithic green algae bloom during coral bleaching and coral white syndrome in response to deeper light penetration into the skeleton [54, 87]. Since endolithic algae have been reported penetrating and can apparently cause lesions of the coral tissue $[87,88]$, it seems possible that the increase in algal biomass during coral bleaching can affect the health status of the coral animal and its susceptibility to pathogens. Data also suggest the coral skeleton as a potential reservoir of the cyanobacterium Phormidium corallyictum causing the deadly black band disease [89].

Besides potential pathogens, the coral skeleton may also harbour beneficial microorganisms playing a role in coral resilience and recovery from disturbances-a proposition known as the skeleton reservoir hypothesis [6, 42]. Many microorganisms that are regarded as functionally important in coral tissues (e.g. Endozoicomonas spp.) also occur in coral skeletons [2, 23, 62, 90]. The notion that biodiversity begets stability is a central principle in ecology [91, 92], suggesting that the highly diverse skeletal ecosystem should be more resilient to stressors than other parts of the coral and potentially act as a safe-house for coral microbiota. In fact, it has been demonstrated that the microbial community present in coral skeletons is more resilient to high $p \mathrm{CO}_{2}$ than that in coral tissues [42]. Symbiodiniaceae play an important role in maintaining $\mathrm{pH}$ homeostasis in the coral tissue [93], and it is possible that the abundant endolithic algae contribute to the buffering capacity of the skeletal environment [54]. Analogous to the human appendix, which serves as a refuge for gut microorganisms that repopulate the colon after illnesses [94], the skeleton may also play a role in assisting the recovery of the coral microbiome during and after diseases, although this hypothesis still needs validation. Computational modelling is particularly promising to determine which (and when) 
members of the microbiome have key roles in health and resilience (e.g. [95]).

The manipulation of the coral-associated microbiome has been proposed as a promising approach to improve coral tolerance to stress [96-98]. The inoculation of corals with probiotics isolated from coral tissue and surrounding water has been shown to reduce the susceptibility of corals to temperature-induced bleaching [98]. Additionally, genetic engineering targeting the thermotolerance of key symbionts can also enhance the resilience of corals to climate change [99]. Probiotics and genetic engineering may provide a rapid and urgently needed response to coral decline, but it must be noted that the field is in its infancy and substantially more research is needed to understand its efficacy and risks [100]. The potential of using beneficial endolithic microorganisms as probiotics, or the long-term effects of manipulating members of the coral microbiome on the endolithic community, is yet to be studied in detail.

\section{Bleaching of the coral, greening of the skeleton}

Heat stress transforms the physico-chemical properties and biology of the coral holobiont and when a coral bleaches, the whole colony including its skeletal microbiota is affected [101]. During bleaching, the symbiosis between the coral and Symbiodiniaceae breaks down, and the latter are degraded or leave their host [102]. Without the Symbiodiniaceae absorbing light and consuming $\mathrm{CO}_{2}$ in the coral tissue, more of the solar irradiance and $\mathrm{CO}_{2}$ is likely to reach the skeleton, which may contribute to fuelling photosynthesis by the endolithic algae that bloom during bleaching events [9, 43, 64, 87].

It has been hypothesised that the endolithic community may protect the corals and help them overcome bleaching periods [9]. During bleaching, the increased light scattering from the skeleton affects any remaining Symbiodiniaceae and can accelerate bleaching-a mechanism known as the optical feedback loop [103, 104]. By absorbing more light, blooming endolithic algae colonising the outer portions of the skeleton may reduce the light scattering from the skeleton, alleviating photic stress for the coral and the remaining Symbiodiniaceae $[55,105]$. Furthermore, photosynthates excreted by Ostreobium may be transferred to the coral animal [8, 77]. Such translocation appears to be enhanced during bleaching events, which may alleviate energy limitation and promote recovery of the coral animal during a temporary loss of Symbiodiniaceae [9]. While the translocation mechanism is unknown, it may be aided by Ostreobium filaments growing toward the coral tissue.

Bleaching-induced stimulation of endolithic photosynthesis is likely to affect the physico-chemical conditions in the skeleton, with downstream effects on microbiota and the coral animal, but little is known about these processes. We hypothesise that the $\mathrm{O}_{2}$ gradient (Fig. 4) will intensify due to increased photosynthesis, also leading to stronger diurnal $\mathrm{pH}$ fluctuations. It also seems likely that carbohydrates produced by endolithic photosynthesis will become available to other members of the microbiome. We hypothesise that this will lead to changes in the community composition and function of other microbes and may also stimulate the development of diverse pathogens. Metagenomic work on coral tissue has indeed shown that the microbiome of bleached corals is enriched in carbohydrate processing and there is an increase in virulence-associated genes $[101,106]$, but the causes for these changes are not fully understood and the link between processes happening in the skeleton and the coral tissue is yet to be studied in detail.

There is no doubt that bleaching has a severe influence on the coral holobiont and its microbiome constituents. While such stress-induced changes in the composition and functioning of microbiomes are starting to be understood for the coral tissue, many questions remain about what happens in the skeleton. The endolithic algal blooms can play a potentially important role in photoprotection and probably in transfer of photosynthates to the coral animal during and after bleaching events. However, the actual changes in physico-chemical microenvironments and skeletal microbiome structure have not been described, and detailed information about interactions between endolithic microbes and the coral host is not currently available. Because of the likely importance of the skeletal microbiome, we consider this a very promising avenue for future research.

\section{Conclusions}

This review highlights that the coral skeleton is much more than the mere structural support of corals. It is a key compartment of the coral holobiont that harbours a diverse and highly structured microbial community that can affect the coral in various ways. While our knowledge about this aspect of the holobiont has grown substantially in the past few years, many open questions remain. Characterising the roles performed by the various endolithic microbial species and their relevance in the holobiont remains a difficult task given the challenges involved in studying rock-dwelling organisms, the vast number of microbial species involved and the sparse information available. How do skeletal micro-niches vary across coral species and with skeletal traits (e.g. coral morphology and density)? What changes in microbial community structure and function occur during the Ostreobium bloom that follows coral bleaching, and 
what is the net effect of beneficial and detrimental effects on the coral? What are the eco-physiological differences between cryptic endolithic algal lineages, and those that bloom during coral bleaching? What is the relative contribution of the skeletal microbiome to nutrient cycling and coral nutrition during coral health and disease, and which skeletal microbes play key roles for the coral animal? Is there co-evolution between coral and endoliths, or do ecological processes suffice to explain the correlation between endolithic community composition and coral phylogeny? We hope that by providing an overview of the current knowledge on the coral skeleton, and identifying knowledge gaps, this paper will stimulate further research into this hidden, yet important microbial reef habitat.

\section{Abbreviation}

DNA: Deoxyribonucleic acid

\section{Acknowledgements}

We thank our lab members for engaging discussions and Ming Fen Eileen Lee for drawing the illustrations used in Fig. 1.

\section{Authors' contributions}

FR, VRM and HV conceptualised the manuscript, wrote the first draft and edited subsequent versions. LLB, MK and MM contributed ideas and commented on the text. All authors read and approved the final manuscript.

\section{Funding}

Funding was provided by the University of Melbourne (RGSS to HV) and the Holsworth Wildlife Research Endowment (to FR).

\section{Availability of data and materials}

Not applicable

\section{Ethics approval and consent to participate}

Not applicable

\section{Consent for publication}

Not applicable

\section{Competing interests}

The authors declare that they have no competing interests.

\section{Author details}

${ }^{1}$ School of BioSciences, University of Melbourne, Parkville 3010, Australia. ${ }^{2}$ Marie Bashir Institute for Infectious Diseases and Biosecurity, Sydney Medical School, Westmead Clinical School, The University of Sydney, Sydney, NSW 2006, Australia. ${ }^{3}$ Marine Biological Section, University of Copenhagen Strandpromenaden 5, DK-3000 Helsingør, Denmark. ${ }^{4}$ Climate Change Cluster, University of Technology Sydney, Ultimo, NSW 2007, Australia. ${ }^{5}$ Pennsylvania State University, University Park, PA 16802, USA

Received: 16 May 2019 Accepted: 17 October 2019

Published online: 12 December 2019

\section{References}

1. Hernandez-Agreda A, Gates RD, Ainsworth TD. Defining the core microbiome in corals' microbial soup. Trends Microbiol. 2017;25:125-40.

2. Marcelino VR, Verbruggen H. Multi-marker metabarcoding of coral skeletons reveals a rich microbiome and diverse evolutionary origins of endolithic algae. Sci Rep. 2016;6:31508.

3. Peixoto RS, Rosado PM, Leite DCA, Rosado AS, Bourne DG. Beneficial microorganisms for corals (BMC): proposed mechanisms for coral health and resilience. Front Microbiol. 2017;8:341.
4. Parkinson JE, Banaszak AT, Altman NS, LaJeunesse TC, Baums IB. Intraspecific diversity among partners drives functional variation in coral symbioses. Sci Rep. 2015;5:15667.

5. LaJeunesse TC, Parkinson JE, Gabrielson PW, Jeong HJ, Reimer JD, Voolstra $C R$, Santos SR. Systematic revision of Symbiodiniaceae highlights the antiquity and diversity of coral endosymbionts. Curr Biol. 2018;28:25702580.e2576.

6. Marcelino VR, van Oppen MJ, Verbruggen H. Highly structured prokaryote communities exist within the skeleton of coral colonies. ISME J. 2018;12: 300-3.

7. Yang S-H, Tandon K, Lu C-Y, Wada N, Shih C-J, Hsiao SS-Y, Jane W-N, Lee TC, Yang C-M, Liu C-T, et al. Metagenomic, phylogenetic, and functional characterization of predominant endolithic green sulfur bacteria in the coral Isopora palifera. Microbiome. 2019;7:3

8. Sangsawang L, Estela Casareto B, Ohba H, Vu HM, Meekaew A, Suzuki T, Yeemin T, Suzuki Y. ${ }^{13} \mathrm{C}$ and ${ }^{15} \mathrm{~N}$ assimilation and organic matter translocation by the endolithic community in the massive coral Porites lutea. R Soc Open Sci. 2017:4:171201.

9. Fine M, Loya Y. Endolithic algae: an alternative source of photoassimilates during coral bleaching. Proc R Soc Lond B Biol Sci. 2002;269:1205-10.

10. Reyes-Nivia C, Diaz-Pulido G, Kline D, Guldberg O-H, Dove S. Ocean acidification and warming scenarios increase microbioerosion of coral skeletons. Glob Chang Biol. 2013;19:1919-29.

11. Kühl M, Holst G, Larkum AW, Ralph PJ. Imaging of oxygen dynamics within the endolithic algal community of the massive coral Porites lobata. J Phycol. 2008:44:541-50

12. Magnusson SH, Fine M, Kühl M. Light microclimate of endolithic phototrophs in the scleractinian corals Montipora monasteriata and Porites cylindrica. Mar Ecol Prog Ser. 2007;332:119-28.

13. Marcelino VR, Verbruggen $H$. Reference datasets of tufA and UPA markers to identify algae in metabarcoding surveys. Data Brief. 2017;11:273-6.

14. Yang SH, Lee S, Huang CR, Tseng CH, Chiang PW, Chen CP, Chen HJ, Tang SL. Prevalence of potential nitrogen-fixing, green sulfur bacteria in the skeleton of reef-building coral Isopora palifera. Limnol Oceanogr. 2016;61:1078-86.

15. Golubic S, Radtke G, Le Campion-Alsumard T. Endolithic fungi in marine ecosystems. Trends Microbiol. 2005:13:229-35.

16. Priess K, Le Campion-Alsumard T, Golubic S, Gadel F, Thomassin BA. Fungi in corals: black bands and density-banding of Porites lutea and P. lobata skeleton. Mar Biol. 2000;136:19-27.

17. Le Campion-Alsumard T, Golubic S, Priess K. Fungi in corals: symbiosis or disease? Interaction between polyps and fungi causes pearl-like skeleton biomineralization. Mar Ecol Prog Ser. 1995;117:137-47.

18. Bentis CJ, Kaufman L, Golubic S. Endolithic fungi in reef-building corals (order: Scleractinia) are common, cosmopolitan, and potentially pathogenic. Biol Bull. 2000;198:254-60.

19. Domart-Coulon I, Sinclair C, Hill R, Tambutté S, Puverel S, Ostrander G. A basidiomycete isolated from the skeleton of Pocillopora damicornis (Scleractinia) selectively stimulates short-term survival of coral skeletogenic cells. Mar Biol. 2004;144:583-92.

20. Li J, Chen Q, Long L-J, Dong J-D, Yang J, Zhang S. Bacterial dynamics within the mucus, tissue and skeleton of the coral Porites lutea during different seasons. Sci Rep. 2014;4:7320

21. DiSalvo $\mathrm{LH}$. Isolation of bacteria from the corallum of Porites lobata (Vaughn) and its possible significance. Am Zool. 1969;9:735-40.

22. Kendrick B, Risk MJ, Michaelides J, Bergman K. Amphibious microborers: bioeroding fungi isolated from live corals. Bull Mar Sci. 1982;32:862-7.

23. Ainsworth TD, Krause L, Bridge T, Torda G, Raina JB, Zakrzewski M, Gates RD, Padilla-Gamino JL, Spalding HL, Smith C, et al. The coral core microbiome identifies rare bacterial taxa as ubiquitous endosymbionts. ISME J. 2015:9:2261-74.

24. Del Campo J, Pombert JF, Slapeta J, Larkum A, Keeling PJ. The 'other' coral symbiont: Ostreobium diversity and distribution. ISME J. 2017:11:296-9.

25. Wegley L, Edwards R, Rodriguez-Brito B, Liu H, Rohwer F. Metagenomic analysis of the microbial community associated with the coral Porites astreoides. Environ Microbiol. 2007;9:2707-19.

26. Le Campion-Alsumard T, Golubic S, Hutchings P. Microbial endoliths in skeletons of live and dead corals: Porites lobata (Moorea, French Polynesia). Mar Ecol Prog Ser. 1995;117:149-57.

27. Meron D, Rodolfo-Metalpa R, Cunning R, Baker AC, Fine M, Banin E. Changes in coral microbial communities in response to a natural $\mathrm{pH}$ gradient. ISME J. 2012;6:1775. 
28. Pollock FJ, McMinds R, Smith S, Bourne DG, Willis BL, Medina M, Thurber RV, Zaneveld JR. Coral-associated bacteria demonstrate phylosymbiosis and cophylogeny. Nat Commun. 2018;9:4921.

29. Odum HT, Odum EP. Trophic structure and productivity of a windward coral reef community on Eniwetok Atoll. Ecol Monogr. 1955;25:291-320.

30. Tribollet $\mathrm{A}$. The boring microflora in modern coral reef ecosystems: a review of its roles. In: Wisshak M, Tapanila L, editors. Current Developments in Bioerosion. Berlin: Springer; 2008. p. 67-94.

31. Gonzalez-Zapata FL, Gómez-Osorio S, Sánchez JA. Conspicuous endolithic algal associations in a mesophotic reef-building coral. Coral Reefs. 2018;37:705-9.

32. Bak R, Laane R. Annual black bands in skeletons of reef corals (Scleractinia) Mar Ecol Prog Ser. 1987;38:169-75.

33. Alker AP, Smith GW, Kim K. Characterization of Aspergillus sydowii (Thom et Church), a fungal pathogen of Caribbean Sea fan corals. Hydrobiologia. 2001;460:105-11

34. Work TM, Aeby GS, Stanton FG, Fenner D. Overgrowth of fungi (endolithic hypermycosis) associated with multifocal to diffuse distinct amorphous dark discoloration of corals in the Indo-Pacific. Coral Reefs. 2008:27:663.

35. Försterra G, Häussermann V. Unusual symbiotic relationships between microendolithic phototrophic organisms and azooxanthellate cold-water corals from Chilean fjords. Mar Ecol Prog Ser. 2008;370:121-5.

36. Hoeksema BW. Forever in the dark: the cave-dwelling azooxanthellate reef coral Leptoseris troglodyta sp. n.(Scleractinia, Agariciidae). ZooKeys. 2012;228:21-37.

37. Kahng SE, Hochberg EJ, Apprill A, Wagner D, Luck DG, Perez D, Bidigare RR. Efficient light harvesting in deep-water zooxanthellate corals. Mar Ecol Prog Ser. 2012:455:65-77.

38. Gutner-Hoch E, Fine M. Genotypic diversity and distribution of Ostreobium quekettii within scleractinian corals. Coral Reefs. 2011;30:643-50

39. Pica D, Tribollet A, Golubic S, Bo M, Di Camillo CG, Bavestrello G, Puce S. Microboring organisms in living stylasterid corals (Cnidaria, Hydrozoa). Mar Biol Res. 2016;12:573-82.

40. Rohwer F, Seguritan V, Azam F, Knowlton N. Diversity and distribution of coral-associated bacteria. Mar Ecol Prog Ser. 2002;243:1-10.

41. Littman RA, Willis BL, Pfeffer C, Bourne DG. Diversities of coral-associated bacteria differ with location, but not species, for three acroporid corals on the Great Barrier Reef. FEMS Microbiol Ecol. 2009;68:152-63.

42. Marcelino VR, Morrow KM, van Oppen MJ, Bourne DG, Verbruggen H. Diversity and stability of coral endolithic microbial communities at a naturally high pCO2 reef. Mol Ecol. 2017;26:5344-57.

43. Shashar N, Stambler N. Endolithic algae within corals-life in an extreme environment. J Exp Mar Biol Ecol. 1992;163:277-86.

44. Massé A, Domart-Coulon I, Golubic S, Duché D, Tribollet A. Early skeletal colonization of the coral holobiont by the microboring Ulvophyceae Ostreobium sp. Sci Rep. 2018:8:2293.

45. Falini G, Fermani S, Goffredo S. Coral biomineralization: a focus on intraskeletal organic matrix and calcification. Semin Cell Dev Biol. 2015;46:17-26.

46. Marcelino LA, Westneat MW, Stoyneva V, Henss J, Rogers JD, Radosevich A, Turzhitsky V, Siple M, Fang A, Swain TD, et al. Modulation of lightenhancement to symbiotic algae by light-scattering in corals and evolutionary trends in bleaching. PLoS One. 2013:8:e61492.

47. Radecker N, Pogoreutz C, Voolstra CR, Wiedenmann J, Wild C. Nitrogen cycling in corals: the key to understanding holobiont functioning? Trends Microbiol. 2015;23:490-7.

48. Salih A, Larkum A, Cox G, Kühl M, Hoegh-Guldberg O. Fluorescent pigments in corals are photoprotective. Nature. 2000;408:850.

49. Halldal P. Photosynthetic capacities and photosynthetic action spectra of endozoic algae of the massive coral Favia. Biol Bull. 1968;134:411-24.

50. Shibata K, Haxo FT. Light transmission and spectral distribution through epiand endozoic algal layers in the brain coral, Favia. Biol Bull. 1969;136:461-8.

51. Wilhelm C, Jakob T. Uphill energy transfer from long-wavelength absorbing chlorophylls to PS II in Ostreobium sp. is functional in carbon assimilation. Photosynth Res. 2006;87:323.

52. Chen M, Schliep M, Willows RD, Cai Z-L, Neilan BA, Scheer H. A red-shifted chlorophyll. Science. 2010;329:1318-9.

53. Behrendt L, Trampe E, Larkum A, Qvortrup K, Norman A, Chen M, Ralph P, Sørensen S, Kühl M. Endolithic chlorophyll d-containing cyanobacteria. ISME J. 2011:5:1072-6.

54. Tribollet A, Chauvin A, Cuet P. Carbonate dissolution by reef microbial borers: a biogeological process producing alkalinity under different pCO2 conditions. Facies. 2019;65:9.
55. Enríquez S, Méndez ER, Prieto RI. Multiple scattering on coral skeletons enhances light absorption by symbiotic algae. Limnol Oceanogr. 2005;50:1025-32.

56. Shashar N, Cohen Y, Loya Y, Sar N. Nitrogen fixation (acetylene reduction) in stony corals: evidence for coral-bacteria interactions. Mar Ecol Prog Ser. 1994;11:259-64.

57. Albrecht M, Gotelli N. Spatial and temporal niche partitioning in grassland ants. Oecologia. 2001;126:134-41.

58. Louca S, Polz MF, Mazel F, Albright MB, Huber JA, O'Connor MI, Ackermann M, Hahn AS, Srivastava DS, Crowe SA. Function and functional redundancy in microbial systems. Nat Ecol Evol. 2018;1:936-43.

59. Cordero OX, Datta MS. Microbial interactions and community assembly at microscales. Curr Opin Microbiol. 2016:31:227-34.

60. Loreau M, de Mazancourt C. Biodiversity and ecosystem stability: a synthesis of underlying mechanisms. Ecol Lett. 2013;16:106-15.

61. Sprockett D, Fukami T, Relman DA. Role of priority effects in the early-life assembly of the gut microbiota. Nat Rev Gastroenterol Hepatol. 2018;15:197.

62. Williams AD, Brown BE, Putchim L, Sweet MJ. Age-related shifts in bacterial diversity in a reef coral. PLoS One. 2015;10:e0144902.

63. Clements KD, German DP, Piché J, Tribollet A, Choat JH. Integrating ecological roles and trophic diversification on coral reefs: multiple lines of evidence identify parrotfishes as microphages. Biol J Linn Soc. 2016:120:729-51.

64. Diaz-Pulido GD, McCook LJ. The fate of bleached corals: patterns and dynamics of algal recruitment. Mar Ecol Prog Ser. 2002;232:115-28.

65. Grange JS, Rybarczyk H, Tribollet A. The three steps of the carbonate biogenic dissolution process by microborers in coral reefs (New Caledonia). Environ Sci Pollut Res. 2015:22:13625-37.

66. Lartaud F, Galli G, Raza A, Priori C, Benedetti M, Cau A, Santangelo G, lannell M, Solidoro C, Bramanti L. Growth patterns in Long-Lived coral species. In: Rossi S, Bramanti L, Gori A, Orejas Saco del Valle C, editors. Marine animal forests. Cham: Springer International Publishing; 2015. p. 1-32.

67. Mollica NR, Cohen AL, Alpert AE, Barkley HC, Brainard RE, Carilli JE, DeCarlo TM, Drenkard EJ, Lohmann P, Mangubhai S. Skeletal records of bleaching reveal different thermal thresholds of Pacific coral reef assemblages. Coral Reefs. 2019:38:1-15.

68. Cohen AL, Smith SR, McCartney MS, van Etten J. How brain corals record climate: an integration of skeletal structure, growth and chemistry of Diploria labyrinthiformis from Bermuda. Mar Ecol Prog Ser. 2004;271:147-58.

69. Pelejero C, Calvo E, McCulloch MT, Marshall JF, Gagan MK, Lough JM, Opdyke BN. Preindustrial to modern interdecadal variability in coral reef $\mathrm{pH}$. Science. 2005;309:2204.

70. Druffel ER. Detection of El Nino and decade time scale variations of sea surface temperature from banded coral records: implications for the carbon dioxide cycle. Geophysical Monogr Ser. 1985;32:111-22.

71. Carriquiry JD, Risk MJ, Schwarcz HP. Stable isotope geochemistry of corals from Costa Rica as proxy indicator of the El Niño/southern oscillation (ENSO). Geochim Cosmochim Acta. 1994;58:335-51.

72. Cuny-Guirriec K, Douville E, Reynaud S, Allemand D, Bordier L, Canesi M, Mazzoli C, Taviani M, Canese S, McCulloch M, et al. Coral Li/Mg thermometry: caveats and constraints. Chem Geol. 2019:523:162-78.

73. Murray J, Prouty NG, Peek S, Paytan A. Coral skeleton $\delta 15 \mathrm{~N}$ as a tracer of historic nutrient loading to a coral reef in Maui. Hawaii. Sci Rep. 2019;9:5579.

74. DeCarlo TM, Cohen AL, Barkley HC, Cobban Q, Young C, Shamberger KE, Brainard RE, Golbuu Y. Coral macrobioerosion is accelerated by ocean acidification and nutrients. Geology. 2015;43:7-10.

75. Risk MJ, Pagani SE, Elias RJ. Another internal clock: preliminary estimates of growth rates based on cycles of algal boring activity. PALAIOS. 1987;2:323-31.

76. Overmann J, Cypionka H, Pfennig N. An extremely low-light adapted phototrophic sulfur bacterium from the Black Sea. Limnol Oceanogr. 1992:37:150-5.

77. Schlichter D, Zscharnack B, Krisch H. Transfer of photoassimilates from endolithic algae to coral tissue. Naturwissenschaften. 1995;82:561-4.

78. Schlichter D. Nutritional strategies of cnidarians: the absorption, translocation and utilization of dissolved nutrients by Heteroxenia fuscescens. Am Zool. 1982;22:659-69.

79. Risk MJ, Muller HR. Porewater in coral heads: evidence for nutrient regeneration. Limnol Oceanogr. 1983;28:1004-8.

80. Ferrer LM, Szmant AM. Nutrient regeneration by the endolithic community in coral skeletons. In: Proceedings of the 6th International Coral Reef Symposium, vol. 2; 1988. p. 1-4. 
81. Nelson HR, Altieri AH. Oxygen: the universal currency on coral reefs. Coral Reefs. 2019;38:177-98.

82. Tribollet A, Golubic S. Reef bioerosion: agents and processes. In: Dubinsky Z, Stambler N, editors. Coral reefs: an ecosystem in transition. Dordrecht: Springer Netherlands; 2011. p. 435-49.

83. Glynn PW, Manzello DP. Bioerosion and coral reef growth: a dynamic balance. In: Coral reefs in the Anthropocene. Dordrecht: Springer; 2015. p. 67-97.

84. Tribollet A, Godinot C, Atkinson M, Langdon C. Effects of elevated pCO2 on dissolution of coral carbonates by microbial euendoliths. Glob Biogeochem Cycles. 2009;23:1-7.

85. Egan S, Gardiner M. Microbial dysbiosis: rethinking disease in marine ecosystems. Front Microbiol. 2016;7:991.

86. Bourne DG, Morrow KM, Webster NS. Insights into the coral microbiome: underpinning the health and resilience of reef ecosystems. Annu Rev Microbiol. 2016;70:317-40.

87. Fine $M$, Roff G, Ainsworth TD, Hoegh-Guldberg O. Phototrophic microendoliths bloom during coral "white syndrome". Coral Reefs. 2006;25:577-81.

88. Peters EC. A survey of cellular reactions to environmental stress and disease in Caribbean scleractinian corals. Helgoländer Meeresuntersuchungen. 1984;37:113-37.

89. Miller AW, Blackwelder P, Al-Sayegh H, Richardson LL. Fine-structural analysis of black band disease-infected coral reveals boring cyanobacteria and novel bacteria. Dis Aquat Org. 2011;93:179-90.

90. Sweet M, Croquer A, Bythell J. Bacterial assemblages differ between compartments within the coral holobiont. Coral Reefs. 2011;30:39-52.

91. Tilman D, Downing JA. Biodiversity and stability in grasslands. Nature. 1994:367:363.

92. Loreau M, Mouquet N, Gonzalez A. Biodiversity as spatial insurance in heterogeneous landscapes. Proc Natl Acad Sci. 2003;100:12765-70

93. Gibbin EM, Putnam HM, Davy SK, Gates RD. Intracellular pH and its response to CO2-driven seawater acidification in symbiotic versus non-symbiotic coral cells. J Exp Biol. 2014;217:1963-9.

94. Bollinger RR, Barbas AS, Bush EL, Lin SS, Parker W. Biofilms in the large bowel suggest an apparent function of the human vermiform appendix. J Theor Biol. 2007;249:826-31.

95. Li J, Convertino M. Optimal microbiome networks: macroecology and criticality. Entropy. 2019;21:506.

96. Damjanovic K, Blackall L, Webster N, van Oppen M. The contribution of microbial biotechnology to mitigating coral reef degradation. Microb Biotechnol. 2017;10:1236-43.

97. Epstein HE, Torda G, Munday PL, van Oppen MJH. Parental and early life stage environments drive establishment of bacterial and dinoflagellate communities in a common coral. ISME J. 2019;13:1635-8.

98. Rosado PM, Leite DCA, Duarte GAS, Chaloub RM, Jospin G, Nunes da Rocha U, Saraiva JP, Dini-Andreote F, Eisen JA, Bourne DG, Peixoto RS. Marine probiotics: increasing coral resistance to bleaching through microbiome manipulation. ISME J. 2019;13:921-36.

99. Levin RA, Voolstra CR, Agrawal S, Steinberg PD, Suggett DJ, van Oppen $\mathrm{MJH}$. Engineering strategies to decode and enhance the genomes of coral symbionts. Front Microbiol. 2017:8:1220.

100. Sweet M, Ramsey A, Bulling M. Designer reefs and coral probiotics: great concepts but are they good practice? Biodiversity. 2017;18:19-22.

101. Littman R, Willis BL, Bourne DG. Metagenomic analysis of the coral holobiont during a natural bleaching event on the Great Barrier Reef. Environ Microbiol Rep. 2011;3:651-60.

102. van Oppen MJ, Lough JM. Coral bleaching. Cham: Springer International Publishing; 2008

103. Swain TD, Lax S, Lake N, Grooms H, Backman V, Marcelino LA. Relating coral skeletal structures at different length scales to growth, light availability to Symbiodinium, and thermal bleaching. Front Mar Sci. 2018;5:450.

104. Wangpraseurt D, Holm JB, Larkum AWD, Pernice M, Ralph PJ, Suggett DJ, Kühl M. In vivo microscale measurements of light and photosynthesis during coral bleaching: evidence for the optical feedback loop? Front Microbiol. 2017;8:59

105. Yamazaki SS, Nakamura T, Yamasaki H. Photoprotective role of endolithic 817 algae colonized in coral skeleton for the host photosynthesis. In: Allen JF, Gantt E, Golbeck JH, Osmond B, editors. Photosynthesis. Energy from the Sun. Dordrecht: Springer; 2008. p. 1391-5.
106. Thurber RV, Willner-Hall D, Rodriguez-Mueller B, Desnues C, Edwards RA Angly F, Dinsdale E, Kelly L, Rohwer F. Metagenomic analysis of stressed coral holobionts. Environ Microbiol. 2009;11:2148-63.

\section{Publisher's Note}

Springer Nature remains neutral with regard to jurisdictional claims in published maps and institutional affiliations.
Ready to submit your research? Choose BMC and benefit from:

- fast, convenient online submission

- thorough peer review by experienced researchers in your field

- rapid publication on acceptance

- support for research data, including large and complex data types

- gold Open Access which fosters wider collaboration and increased citations

- maximum visibility for your research: over $100 \mathrm{M}$ website views per year

At BMC, research is always in progress.

Learn more biomedcentral.com/submissions 